\title{
PENGARUH REBUSAN DAUN UBI JALAR (IPOMOEA BATATAS) TERHADAP KADAR HEMOGLOBIN PADA IBU HAMIL DI WILAYAH KERJA PUSKESMAS TIRON KABUPATEN KEDIRI
}

\author{
The Effect of Sweet Potato Leaf Stew (Ipomoe Batatas) on Hemoglobin Levels in Pregnant \\ Women In The Work Area Of The Tiron Health Center Kediri Regency
}

\author{
Dewi Kartika Sari ${ }^{1}$, Putri Wahyu Wigati² \\ 1, 2 Fakultas Ilmu Kesehatan Universitas Kadiri
}

\author{
Riwayat artikel \\ Diajukan: September 2020 \\ Diterima: Maret 2021.
}

\section{PenulisKorespondensi: \\ - Dewi Kartika Sari \\ - Fakultas Ilmu \\ Kesehatan Universitas \\ Kadiri \\ - dewikartika@unik- kediri.ac.id}

\section{Kata Kunci: \\ Daun Ubi Jalar, Kadar Hemoglobin, Ibu Hamil}

\begin{abstract}
Abstrak
Anemia adalah suatu kondisi dimana kadar hemoglobin dibawah normal. Anemia yang terjadi pada ibu hamil sangat berkaitan dengan mortalitas dan morbiditas pada ibu dan bayi, risiko abortus dan IUFD, berat bayi lahir rendah dan prematur. Survey awal yang dilakukan di wilayah kerja Puskesmas Tiron pada periode Juni- Juli 2019 dari ibu hamil, (60\%) ibu hamil mengalami anemia dan (40\%) normal, hal tersebut menunjukan bahwa masih tingginya kejadian anemia di wilayah kerja Puskesmas Tiron Kabupaten Kediri. Tujuan dilakukan penelitian ini adalah menganalisis pengaruh rebusan daun ubi jalar terhadap kadar hemoglobin pada ibu hamil.

Penelitian ini adalah penelitian quasi eksperimen, dengan One Group Pre-test and post test design dengan memberikan rebusan daun ubi jalar selama 7 hari. Teknik pengambilan sampel menggunakan Total Sampling. Subject dari penelitian ini adalah ibu hamil dengan kadar hemoglobin jika Trimester $2<10,5 \mathrm{gr} / \mathrm{dl}$ dan jika Trimester $3<$ $11 \mathrm{gr} / \mathrm{dl}$. Penelitian ini dilakukan wilayah kerja puskesmas tiron kabupaten kediri. Uji analisisnya menggunakan paired T-Test. hasil analisis dengan paired T- Test menunjukan bahwa $\mathrm{p}$ value 0,000 atau $\mathrm{p}$ value $<0,05$ yang berarti ada pengaruh rebusan daun ubi jalar terhadap kadar hemoglobin pada ibu hamil dengan selisih rata rata kadar hemoglobin sebelum dan sesudah perlakuan sebesar 1,418gr/dl. Bahwa adanya pengaruh rebusan daun ubi jalar terhadap kadar hemoglobin ibu hamil dapat digunakan sebagai alternatif untuk meningkatkan kadar hemoglobin ibu hamil
\end{abstract}

Abstract
Anemia is a condition.where the hemoglobin level is below normal. Anemia that occurs in pregnant.women is closely related to maternal and infant mortality and morbidity, risk of abortion and IUFD, low birth weight and premature babies. The initial survey conducted in the Tiron Health Center working area in the period June-July 2019 from pregnant women, $(60 \%)$ pregnant women experienced anemia and (40\%) normal, this shows that anemia is still incidence in the working area of the Tiron Puskesmas, Kediri Regency. The purpose of this study was to analyze the effect of sweet potato leaf stew on hemoglobin levels in pregnant women.

This study was a quasi-experimental study, with One Group Pre-test and posttest design by giving boiled sweet potato leaves for 7 days. The sampling technique used total sampling. The subjects of this study were pregnant women with hemoglobin levels if Trimester $2<10.5 \mathrm{~g} / \mathrm{dl}$ and if Trimester $3<11 \mathrm{~g} / \mathrm{dl}$. This research was conducted in the working area of the Tiron Public Health Center, Kediri Regency. Test analysis using paired T-Test. The results of the paired T-Test analysis showed that the $\mathrm{p}$ value was 0.000 or $\mathrm{p}$ value $<0.05$, which means that there was an effect of sweet potato leaf decoction on hemoglobin levels in pregnant women with the average difference in hemoglobin levels before and after treatment of $1.418 \mathrm{gr} / \mathrm{dl}$. that the effect of sweet potato leaf decoction on hemoglobin levels in pregnant women can be used as an alternative to increasing hemoglobin levels of pregnant women. 


\section{Pendahuluan}

Anemia yakni suatu kondisi dimana konsentrasi hemoglobin dibawah nilai batas normal. Ibu hamil merupakan kelompok yang beresiko mengalami anemia (Lestrina, Nurhayati and Martony, 2015). Anemia merupakan indikator untuk melihat gizi buruk dan kesehatan yang buruk. Ibu hamil yang mengalami anemia berpotensi menambah Angka Kematian Ibu (AKI) (Dinas Kesehatan Propinsi JawaTimur, 2017).

Menurut WHO anemia sudah menjadi kasus yang penting (WHO, 2015). Menurut RISKESDAS 2018 terjadi peningkatan kejadian anemia pada ibu hamil di Indonesia dari tahun 2013 sebesar $37,1 \%$ dan meningkat pada tahun 2018 menjadi 48,9\%, dan anemia pada ibu hamil tertinggi yaitu $84,6 \%$ dialami oleh ibu hamil usia 15-24 tahun (Riskesdas 2018, 2018). Survey awal yang dilakukan di wilayah kerja Puskesmas Tiron pada periode Juni- Juli 2019 dari 20 ibu hamil, $12(60 \%)$ ibu hamil mengalami anemia dan $8(40 \%)$ normal, hal tersebut menunjukan bahwa masih tingginya kejadian anemia di wilayah kerja Puskesmas Tiron Kabupaten Kediri.

Upaya Pemerintah dalam mencegah dan mengatasi anemia dengan memberikan tablet $\mathrm{Fe}$ yang diprioritaskan pada ibu hamil namun prevalensi anemia pada ibu hamil masih tetap tinggi (Dinas Kesehatan Propinsi JawaTimur, 2017), maka dari itu perlu dilakukan penanganan anemia secara non farmakologi dengan mengkonsumsi rebusan daun ubi jalar (Ishiguro et al., 2004). Dalam $100 \mathrm{mg}$ daun ubi jalar terkandung $117 \mathrm{mg}$ kalsium, 3,5 mg karoten, 1,8 $\mathrm{mg}$ zat besi , 1,6 $\mathrm{mg}$ vitamin E, 7,2 $\mathrm{mg}$ vitamin $\mathrm{C}$, dan $0,5 \mathrm{mg}$ vitamin $\mathrm{K}$, vitamin $\mathrm{B}$, serta betakaroten (Ishiguro et al., 2004) serta protein selain itu dari hasil penelitian tahun 2011 menemukan bahwa ekstrak daun ubi jalar mampu meningkatkan aktivitas organ-organ yang terlibat dalam pembentukan sel darah merah yang berada pada sum sum tulang belakang dan hati (Osime et al., 2011).

Dengan dilatarbelakangi hal tersebut peneliti sangat tertarik melakukan penelitian tentang pengaruh rebusan daun ubi jalar terhadap kadar hemoglobin pada ibu hamil di Kabupaten Kediri tahun 2020. Penelitian ini sesuasi dengan RIRN 2017-2045 dengan teknologi yang dikembangkan berupa teknologi tentang pangan kesehatan.

\section{Metodologi}

Penelitian ini adalah penelitian quasi.eksperimen, dengan One Group Pre-test and post test design dengan subject ibu hamil yang mengalami anemia, dengan memberikan 10 lembar daun ubi jalar ditambah air $100 \mathrm{ml}$ direbus selama 10 menit dengan api kecil, dan diberikan ibu hamil setiap pagi selama 7 hari berturut turut pada ibu hamil yang mengkonsumsi tablet Fe. Teknik pengambilan sampel menggunakan Total Sampling. Lokasi dari penelitian ini adalah di Wilayah Kerja Puskesmas Tiron Kabupaten Kediri. Penelitian dilakukan Pada bulan Juni- Juli 2020 Penelitian dilakukan wilayah kerja Puskesmas Tiron Kabupaten Kediri.

Penelitian ini juga telah mendapatkan.persetujuan dari komisi.etik penelitian Kesehatan Institute Ilmu Kesehatan STRADA Indonesia dengan nomor 2109/KEPK/VI/2020. Uji analisisnya menggunakan.paired T- Test.

\section{Hasil Dan Pembahasan} 1. Karakteristik Ibu Hamil Trimester II dan III
dengan Anemia

Tabel 1. Karakteristik Responden Bersarkan data Umum

\begin{tabular}{|c|c|c|c|c|}
\hline No & Karakteristik & Kategori & $\mathbf{F}$ & $\%$ \\
\hline \multirow[t]{3}{*}{1} & Usia & $<20$ & 1 & 6,3 \\
\hline & & $20-35$ & 15 & 93,8 \\
\hline & Total & & 16 & 100,0 \\
\hline \multirow[t]{4}{*}{2} & Pendidikan & Dasar & 5 & 31,3 \\
\hline & & Menengah & 5 & 31,3 \\
\hline & & Tinggi & 6 & 37,5 \\
\hline & Total & & 16 & 100,0 \\
\hline \multirow[t]{3}{*}{3} & Pekerjaan & IRT & 10 & 62,5 \\
\hline & & Swasta & 6 & 37,5 \\
\hline & Total & & 16 & 100,0 \\
\hline \multirow[t]{3}{*}{4} & Paritas & $\begin{array}{l}\text { Primigravi } \\
\text { da }\end{array}$ & 6 & 37,5 \\
\hline & & $\begin{array}{l}\text { Multigravi } \\
\text { da }\end{array}$ & 10 & 62,5 \\
\hline & Total & & 16 & 100,0 \\
\hline
\end{tabular}

Berdasarkan Tabel. 1 menunjukan bahwa hampir seluruhnya berusia 20-35 tahun, pendidikan hampir setengahnya adalah dasar dan menengah. Berdasarkan pekerjaan sebagian besar adalah Ibu rumah tangga, dan sebagian besar paritasnya adalah multigravida. 
2. Pengaruh Rebusan Daun Ubi.Jalar Terhadap Kadar.Hemoglobin Pada Ibu Hamil

Intervensi menggunakan rebusan daun ubi jalar dilakukan kepada 16 ibu hamil yang mengalami anemia diperoleh hasil rata rata hemoglobin sebelum adalah 9,938 dan rata rata hemoglobin setelah perlakuan adalah 11,056 yang berarti setelah perlakuan dengan menggunakan rebusan daun ubi jalar selama 7 hari kadar hemoglobin rata rata mengalami peningkatan sebesar $1,418 \mathrm{mg} / \mathrm{dl}$

Tabel 2 Pengaruh.rebusanDaun Ubi.Jalar Terhadap Kadar.Hemoglobin Pada Ibu Hamil

\begin{tabular}{lccc}
\hline. & Mean & N & SD \\
\hline $\begin{array}{l}\mathrm{Hb} \\
\text { Sebelum }\end{array}$ & 9,638 & 16 &, 5058 \\
$\begin{array}{l}\text { Hb } \\
\text { Setelah }\end{array}$ & 11,056 & 16 &, 2966 \\
\hline P Value 0.000 & & & \\
\hline
\end{tabular}

Diketahui intervensi menggunakan rebusan daun ubi jalar selama 7 hari berturut turut mampu meningkatkan kadar hemoglobin pada ibu hamil, hal tersebut sejalan dengan penelitian yang dilakuan pada tahun 2017 yang mengatakan bahwa jus daun ubi jalar dapat memperbaiki profil hematologi mencit anemia lebih baik dibandingkan kelompok kontrol (I Ketut Adnyana, Arief Rosmadi, Joseph Iskendiarso Sigit, 2017a).

Ibu hamil rentan terhadap anemia karena meningkatnya jumlah pasokan darah sekitar 20$30 \%$ maka dari itu butuh tambahan mineral dan vitamin untuk proses pembentukan hemoglobin (Rismalinda, 2015) (Kemenkes RI, 2013). Fe memang dibutuhkan pada kehamilan walaupun pemerintah sudah banyak memberikan 90 tablet Fe (Kementerian Kesehatan RI, 2015), namun juga membutuhkan zat pendorong untuk terserapnya Fe (Susiloningtyas, 2012).

Pemberian rebusan daun ubi jalar bisa menjadi alternatif penanganan anemia pada ibu hamil karena jumlah besi, kalsium, dan karoten dalam daun ubi jalan tinggi dibanding dengan daun lainya(Islam, 2006), dalam $100 \mathrm{mg}$ daun ubi jalar terkandung $117 \mathrm{mg}$ kalsium, 3,5 mg karoten, 1,8 mg zat besi , 1,6 mg vitamin $\mathrm{E}, 7,2$ $\mathrm{mg}$ vitamin $\mathrm{C}$, dan $0,5 \mathrm{mg}$ vitamin $\mathrm{K}$, vitamin $\mathrm{B}$, serta beta-karoten (Ishiguro et al., 2004). Penelitian tahun 2007 juga menunjukan ekstrak daun ubi jalar mampu meningkatkan pembentukan sel darah merah di sumsum tulang belakang dan hati (Osime et al., 2011).

Hal ini juga sejalan dengan penelitian yang dilakukan di bandung menemukan bahwa daun ubi jalar mampu memperbaiki profil hematologi dan mempertahankan hidup mencit yang anemia(I Ketut Adnyana, Arief Rosmadi, Joseph Iskendiarso Sigit, 2017b), penelitian ini juga sejalan dengan penelitian pada tahun 2015 dan 2018 yang menyakan bahwa setelah pemberian intervensi dengan rebusan daun ubi jalan kadar hemoglobin pada ibu hamil meningkat (Hutabarat and Widyawati, 2018) (Kuswati, 2015).

Berdasarkan penelitan daun ubi jalar mengandung banyak vitamin dan mineral yang sangat berguna untuk pembentukan darah di sum sum tulang belakang, maka dari itu dengan adanya rebusan daun ubi jalar mampu meningkatkan kadar hemoglobin pada ibu hamil. Sehingga diharapkan jika kadar hemoglobin ibu hamil meningkat maka anemia teratasi dan ibu bayi dalam keadaan sehat.

\section{Daftar Pustaka}

Dinas Kesehatan Propinsi JawaTimur (2017) 'Profil Kesehatan Propinsi Jawa Timur 2017', Nucleic Acids Research.

Hutabarat, N. C. and Widyawati, M. N. (2018) 'The Effect of Sweet Potato Leaf Decoction and Iron Tablet against Increased Hemoglobin Levels in Pregnant Women ( Pengaruh Pemberian Rebusan Daun Ubi Jalar dan Tablet Fe terhadap Peningkatan Kadar Hemoglobin Ibu Hamil )', 1(2), pp. 59-65.

I Ketut Adnyana, Arief Rosmadi, Joseph Iskendiarso Sigit, S. F. R. (2017a) 'Pengaruh Pemberian Jus Daun Katuk, Jus Daun Ubi Jalar, dan Kefir Terhadap Profil Hematologi Mencit Anemia yang Diinduksi Alumunium Sulfat', Acta Pharmaceutica Indonesia, 37(2), pp. 54-58.

I Ketut Adnyana, Arief Rosmadi, Joseph Iskendiarso Sigit, S. F. R. (2017b) 'Pengaruh Pemberian Jus Daun Katuk, Jus Daun Ubi Jalar, dan Kefir Terhadap Profil Hematologi Mencit Anemia yang Diinduksi Alumunium Sulfat', Acta Pharmaceutica Indonesia.

Ishiguro, K. et al. (2004) 'Suioh, a new sweetpotato cultivar for utilization in vegetable greens', in Acta Horticulturae. doi: 10.17660/ActaHortic.2004.637.42.

Islam, S. (2006) 'Sweetpotato (Ipomoea batatas L.) Leaf: Its Potential Effect on Human Health and Nutrition', Journal of Food Science. doi: 10.1111/j.1365-2621.2006.tb08912.x.

Kemenkes RI (2013) 'Angka Kecukupan Gizi 
(AKG)', Kementerian Kesehatan RI.

Kementerian Kesehatan RI (2015) No Title. Stop Kanke. Jakarta Selatan: Kemenkes RI.

Kuswati, E. S. (2015) 'PENGARUH PEMBERIAN MULTIPEL MICRO NUTRIEN (MMN) DITAMBAH EKSTRAK DAUN UBI JALAR DAN TABLET Fe TERHADAP NILAI HEMOGLOBIN IBU HAMIL', Interest : Jurnal Ilmu Kesehatan, 4(2), pp. 107-110.

Lestrina, D., Nurhayati, I. and Martony, O. (2015) 'Pengaruh Promosi Kesehatan Terhadap Peningkatan Pengetahuan Dan Kadar Hemoglobin Pada Wanita Usia Subur Di Desa Paluh Kemiri Kecamatan Lubuk Pakam', Wahana Inovasi.

Osime, E. et al. (2011) 'Effect of sweetpotato leaf (Ipomoea Batatas) extract on some haematological parameters using rabbits', Journal of Medicine and Biomedical Research. doi: 10.4314/jmbr.v7i1-2.44540.

Riskesdas 2018 (2018) 'Hasil Utama Riset Kesehatan Dasar', Kementrian Kesehatan Republik Indonesia. doi: 1 Desember 2013.

Rismalinda (2015) Asuhan Kebidanan Kehamilan. Jakarta: Trans Info Media.

Susiloningtyas, I. (2012) 'PEMBERIAN ZAT BESI (Fe) DALAM KEHAMILAN Oleh: Is Susiloningtyas', Majalah Ilmiah Sultan Agung, 50, p. 128.

WHO (2015) World Health Statistic 2015, Acta Universitatis Agriculturae et Silviculturae Mendelianae Brunensis. 